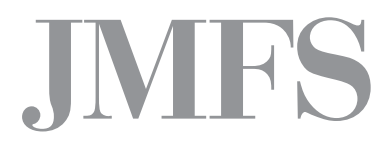

Journal of Management and Financial Sciences
Volume XIII

Issue 41 (June 2020)

pp. $45-60$

SGH Warsaw School of Economics

Collegium of Management and Finance

\title{
Michał Trocki
}

SGH Warsaw School of Economics

ORCID: 0000-0002-0082-489X

\section{Mateusz Juchniewicz}

SGH Warsaw School of Economics

ORCID: 0000-0002-3598-2679

\section{Emil Bukłaha}

SGH Warsaw School of Economics

ORCID: 0000-0002-5271-7885

\section{Socially responsible project management}

\section{ABSTRACT}

In recent years we have observed the global awareness of threats posed by unrestrained and irresponsible growth gaining ground. Hence, continuous searches for sustainable solutions which enable to put in place measures that promote global, national, and local efficiency seem to make sense. This paper aims to examine and assess the current state of affairs and proposes directions for the development of sustainable and socially responsible project-related activities. It explains how the idea of social responsibility emerged as a natural consequence of the evolution of an organisation with respect to sustainable development. Against the background of these notions we define the place and role of project management in socially responsible development and discuss different views on the subject presented by authors from different countries. Theoretical considerations are supplemented with the discussion of the findings of own surveys focused on the role and relevance of social responsibility in project management in organisations active in this field in Poland. It was an exploratory study, the first of its kind in Poland.

Keywords: sustainable development, corporate social responsibility, project social responsibility, project, project management

JEL Classification Codes: A13, L21, M10, M14, O22, Q01, Q56 


\section{Introduction}

Humans have shown concern about what happens to the world around them since the dawn of time and expressed it through their political or religious leaders, intellectuals, artists, entrepreneurs, as well as ordinary people.

In the $20^{\text {th }}$ century, the awareness of a variety of threats - to the mankind, society and individuals - resulting from unrestrained and irresponsible growth, became widely spread as a result of intensive research, educational, and promotional efforts of international organisations, above all the UN, government institutions, professional associations, non-profit organisations, and private individuals.

As a result, a conviction about the need to counteract these threats got disseminated, which took shape in concepts of sustainable development, i.e., development "that meets the needs of the present without compromising the ability of future generations to meet their own needs" [Our Common Future, 1987].

Despite many years of efforts, problems of sustainable development and social responsibility have failed to be resolved in accordance with needs and expectations. Thus, it seems to make sense to expand our considerations to cover new areas of human activity. This paper deals with the very issue.

Sustainable development calls for coherent and responsible actions at all levels of a social organisation: global, regional, national, organisational, or individual. Sustainable development of an organisation referred to as corporate social responsibility (CSR $)^{1}$ has special relevance here because this is the level where effects of development decisions take a concrete shape. The problem of corporate social responsibility is intensively worked on and numerous scientific and practical achievements have been accomplished in this area, which does not mean, however, that the subject has been exhausted.

One of the major research subjects that still needs to be worked out is the problem of project social responsibility within an organisation. Project-related activities are sources of a variety of development benefits as well as threats and negative outcomes.

The importance of the problem stems from the trend referred to as projectification and consists in the growing share and relevance of projects in the economy and in operations of individual organisations that have been observed for some years already [Nieto-Rodrigez, 2012; Schoper, Waldt, Ingason, Friedgeirson, 2017].

The goal of this paper is to examine and assess the current state and postulated development directions of sustainable and socially responsible project activities.

Such an approach triggers research questions addressed in this paper:

- to identify the place and role of project activities within the framework of sustainable development and corporate social responsibility;

1 Polish translation of the term does not fully convey its essence, i.e., placing social responsibility at the level of an organisation. 
- to review and systematically organise the state-of-the-art knowledge and practical achievements in this field;

- to develop a corporate social responsibility model in project activities;

- to carry out studies in socially responsible delivery of projects in organisations active in Poland.

To accomplish the above-listed goals, the authors deployed two types of research methods:

- first, desk research to review previous research findings, classify and systematically organise the existing knowledge;

- second, questionnaire-based studies and statistical analysis of the collected data.

\section{From sustainable development to corporate social responsibility}

Sustainable development postulates have been proposed for many years, e.g., in works by H-C. von Carlowitz, Th. Malthus, A. Pigou and others [von Carlowitz, 1732/2009; Malthus, 1798; Pigou, 1920]. A meaningful opinion was formulated by P. Drucker, who, at the turn of the 1930s and 1940s, argued that economic activity goals should include not just economic performance but also social responsibility [Klimczuk-Kochańska, 2016]. In 1953 the first extensive publication was released on ethics and corporate social responsibility [Bowen, 1953].

After WWII, when international organisations got engaged in the field, the issue significantly gained in importance. The Report of the UN Secretary General U. Thant titled The Problems of Human Environment [Problems..., 1969] was published in 1969. The publication by the Club of Rome of report Limits to Growth released in 1972 became the turning point. The report included a future vision of the growth of the planet, warning about the consequences of population growth and the depletion of natural resources. "If the present growth trends in world population, industrialisation, pollution, food production, and resource depletion continue unchanged, the limits to growth on this planet will be reached sometime within the next one hundred years. The most probable result will be a rather sudden and uncontrollable decline in both population and industrial capacity" [D.H. Meadows, D.I. Meadows, Randers, Behrens, 1972/1973, p. 23]. Following the first one, the Second Report for the Club of Rome titled Mankind at the Turning Point was drafted in 1974 [Mesarović, Pestel, 1975; Mesarović, Pestel, Rączkowska, Rączkowski, 1977].

In 1987 the UN World Commission on Environment and Development at the UN known as the 'Brundtland Commission' after the name of its chairperson Gro Harlem Brundtland, published its report Our Common Future, in which it formulated the postulate of sustainable development, i.e., development that meets the needs of the present generation without compromising the ability of future generations to meet their own needs [Our Common Future, 1987]. Since that moment, the term sustainable development has become the leitmotiv of further discussions and activities. 
In the following years, sustainable development evolved substantially. The first outcome of this evolution consisted in shifting from short-term thinking to a sustainable approach to problems of short-term and long-term development. The second one involved moving from environmental through social to economic issues alongside the so-called Triple Bottom Line (TBL) concept. The concept highlights the equal status of all these bottom lines, the pillars of sustainable development: People, Planet, and Profit (Prosperity) [Eklington, 2004]. The third aspect of the evolution covers shifting from the global approach to sustainable development focused on the fate of the planet through regional, national, sectoral, organisational/institutional problems, down to individual problems of human beings [Roland, Tirole, 2009]. As a result, the scope of interest and engagement into sustainable development matters expanded to cover international organisations, governments, NGOs, professional organisations, economic organisations, moral authorities, and ordinary people [Roland, Tirole, 2009; Silvius, Schipper, 2010]. The bringing of sustainable development down to the level of an organisation laid the foundations for the Corporate Social Responsibility (CSR) concept.

This is how the problems of sustainable development evolved and paved the way for themselves from discussions held in small expert groups through wide discussions in different circles to private exchanges of views.

How the ideas of sustainable development and social responsibility evolved can be traced in Table 1 [Społeczna..., 2019].

Table 1. Evolution of sustainable development and social responsibility concepts

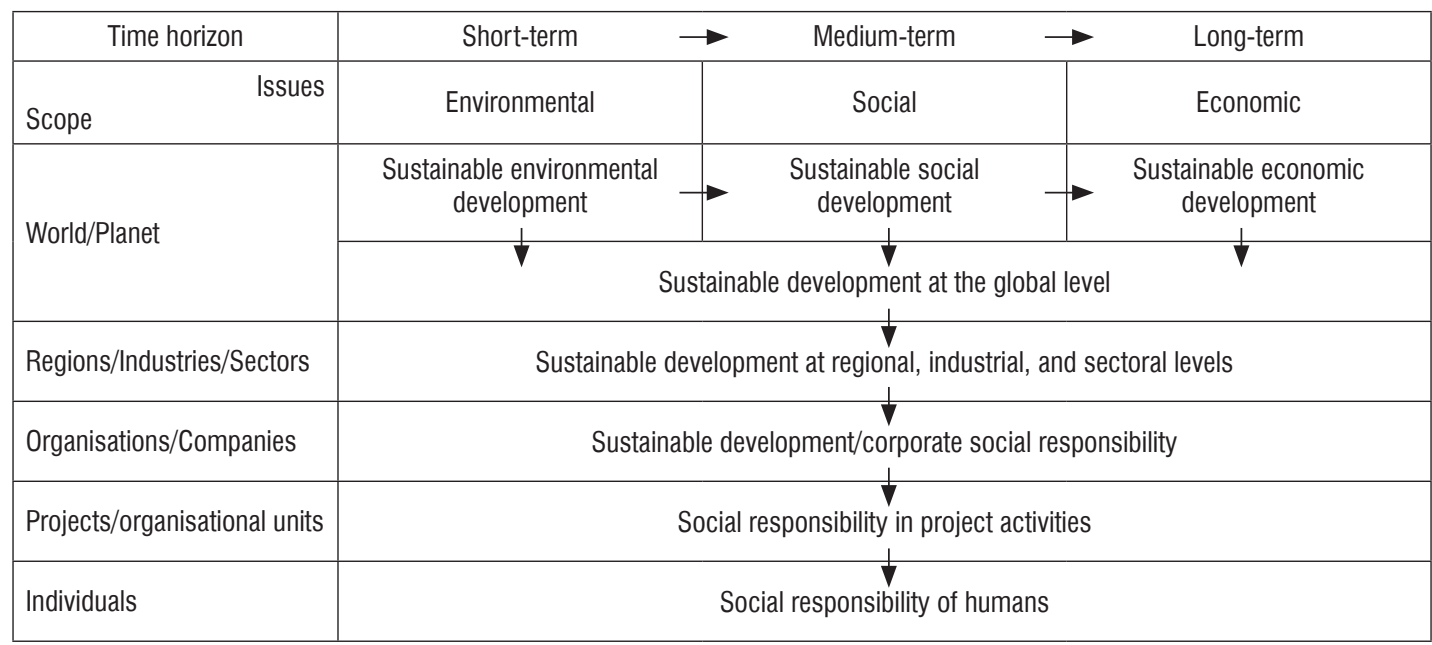

Source: own elaboration based on Społeczna odpowiedzialność działalności projektowej (2019).

For over fifty years, sustainable development concept evolved from an inspiration through problem definition, seeking and generating ideas, and then implementing them until the present times when, on the one hand, the awareness of threats is much bigger and, on the other hand, there are increasingly more controversies [Borys, Czaja, 2009, pp. 51-58; Wołczek, 2014, pp. 207-208]. 
They focus around discussions on:

- principal matters: rate of depletion of resources and its consequences, environmental threats, climate change, economic inequalities between regions, countries, as well as social groups, social and economic disparities, exclusion, exploitation, threats to life and health resulting from wars, conflicts, etc.;

- accountability and burden sharing: should developed countries which have contributed to the present circumstances be held solely responsible or should also developing countries be involved, etc.;

- instruments: legal, PR, ethics, etc.;

- intervention level: global/international organisations (which ones?), regions/regional organisations (which ones?), countries/governments, companies, NGOs, individuals, etc.;

- rate, timetable, milestones, activities, etc.

In order to counteract these existential civilisation challenges, all social forces should be mobilised not only forcefully or by other regulatory means but also by individual awareness of responsibility involved in it. People who professionally deal with implementing projects are among groups which should be active in this field. This is why we need to investigate the place and role of project activities with regard to sustainable development and social responsibility, its opportunities and limitations in this respect and formulate appropriate recommendations.

\section{Socially responsible project management}

For a long time project activities were seen as components of corporate social responsibility, which assumes integrated, sustainable and responsible management of an organisation and includes the responsibility for all problems involved in business operations, relations with the external world and impact upon natural and social environments. Internal aspects of corporate social responsibility - organisational units, projects, etc. - for a long time were not viewed as separate problem areas and were not considered in detail.

Various arguments can be put forward in favour of treating the above issues as separate and promoting corporate social responsibility in project-related activities. The first and major one is the growing share and importance of projects in corporate management referred to as projectification. Currently, ca. 25\% of the global gross domestic product (GDP), i.e., USD 50 trillion, is generated through projects. It is estimated that in 10 years' time the share of projects will reach $35 \%$ of the GDP and the sector of project management will increase by USD 6.61 trillion [Brilman, 2002, p. 318; Nieto-Rodriguez, 2012, p. 38]. In developed economies, the share is higher already, e.g., in Germany it amounts to $34.7 \%$, in Norway $32.6 \%$, and in Iceland 27.7\% [Schoper, Waldt, Ingason, Friedgeirson, 2017]; the same can be said about fast growing economies, such as India (34\%) and China (as much as 45\%). Estimates of the Project Management Institute show that 51 million people around the world are engaged in project management [PMI Annual Report, 2013, p. 1] and by 2020 ca. 15.7 million new jobs 
for project managers will be created globally in the most important sectors [PMI's Industry..., 2010, p. 2]. By 2027 we will have to train and prepare 87.7 million people to perform different functions in projects [Project..., 2017].

The scale and importance of challenges stemming from that can be evidenced by examples of planned and implemented mega projects, such as: high speed railway connection linking London with northern England and Scotland (High Speed 2/UK, USD 45.6 bn), gas pipeline from Russia to Bulgaria (South Stream/Russia, USD 20 bn), next generation air traffic control (NextGen Air Traffic Control System/USA, USD 20 bn), extension of a seaport on the Yellow Sea (Port Qingdao/China, USD 15 bn), etc. [Top 100..., 2010]. Such projects must be implemented in full awareness of the responsibility for environmental, social, and economic consequences, going beyond the interests of organisations which implement these projects.

Hence the problem of organisational ambidexterity, i.e., the need to combine efficiently within one organisation exploitation activities dealing with today's running of the business and exploration (project) activities, i.e. being able to adapt and cope with future changes. This is also what the specificity of projects requires, their complexity, uniqueness, etc., fundamentally different from current operational business. Apart from that, projects and their management exhibit a substantial autonomy resulting, among others, from two-tier subordination of projects to the contracting party (external projects) and to the management of the parent company [Birkinshaw, Gibson, 2004; O’Reilly, Tushman, 2013].

Studies carried out in the early $21^{\text {st }}$ century [Labuschagne, Brent, 2004; Labuschagne, Brent, 2005; Brent, 2005] demonstrated that the involvement of project managers in sustainable development and corporate social responsibility is disproportionally low compared to the impact of projects on sustainable development at all its levels and in all scopes. R. Gereis, M. Huemann and R-A. Martinuzzi concluded that "sustainable development in temporary organisations such as projects or programmes is rarely considered" [Gereis, Huemann, Martinuzzi, 2009, p. 1], while M. Eid came to the conclusion that project management standards "fail to seriously address the sustainability agenda" [Eid, 2009, p. 288]. "Projects can contribute to sustainable development of a company. Thus, one should legitimately expect that sustainable development concepts are reflected in projects and project management. However, although some aspects of sustainable development can be traced in different project management standards, we need to conclude that the integration of sustainability into projects and project management is not fully recognised" [Silvius, Schipper, 2010, p. 6].

The awareness of this fact triggered discussions on the concept of project-related social responsibility. It happened relatively late, in the early $21^{\text {st }}$ century, while at global and local levels sustainability and social responsibility concepts had been evolving intensely for several dozen years already.

The subject of social responsibility in connection with project management activities has gained considerable attention following the speech of M. McKinlay delivered to the World Congress of the International Project Management Association (IPMA) in 2008, in which she appealed to professionals in project management profession to take responsibility for 
sustainability [McKinlay, 2008]. The appeal was favourably received by the community to which it was addressed; since then many professional and research publications have been released - papers, conference materials, books, book chapters - on social responsibility in project activities [Silvius, Schipper, 2014; Økland, 2015; Jakubczyk, Kitowski, 2015].

The discussion led to the approval of concepts of sustainability and social responsibility in project management and defined them as "responsibility for the impact of a project and its outcomes on society and the environment ensured by responding to identifiable needs of internal and external stakeholders of the project, as well as delivering a unique product that has been created in a rational manner without infringing the principles of ethics and morality. It calls for rational striving to achieve a concrete goal, taking account of conditions favouring economic, social and sustainable development across all stages of project management: from the project's initiation to the exploitation of its deliverables" [Jakubczyk, Kitowski, 2015].

A.J.G. Silvius and R. Schipper define social responsibility in project activities as "planning, monitoring, and controlling of project delivery and support processes, with consideration of the environmental, social, and economic aspects of the life-cycle of the project's resources, processes, deliverables and effects, aimed at realising benefits for stakeholders, and performed in a transparent, fair, and ethical way that includes proactive stakeholder participation" [Silvius, Schipper, 2010, p. 6].

Considerations and research into social responsibility in project management lead to the conclusion that the problem:

- is relevant and its importance for corporate social responsibility is growing also at other levels;

- is relevant for efficient delivery of projects in terms of their products and processes;

- should be approached in a relatively autonomous way due to the specificity of projects, their uniqueness and temporary nature, as well as effects often exceeding the framework of just one organisation;

- needs to consider project social responsibility issues in management methodologies practiced by an organisation [Silvius, Schipper, 2014, pp. 40-58).

The initially questioned purposefulness of advancing the practical and theoretical aspects of sustainable project management is now fully recognised. Discussions continue as to its scope. Searches for important balancing principles have resulted in a set of sustainability principles in project management [Agarwal, Kalmár, 2015). These principles concern the balancing of:

- short-term and long-term orientation;

- balancing or harmonising environmental, social, and economic interests;

- global, regional, and local orientation;

- value and ethics;

- stakeholder participation;

- risk reduction;

- transparency and accountability;

- consuming income not capital. 
Views on these principles are presented in Table 2.

The discussion reinforced the conviction that social responsibility in project management should be investigated in five areas: three bottom lines, 'pillars', social responsibility, and two perspectives: products/outcomes and project delivery processes.

Table 2. Views on sustainable project management

\begin{tabular}{|c|c|c|c|c|c|c|c|c|}
\hline 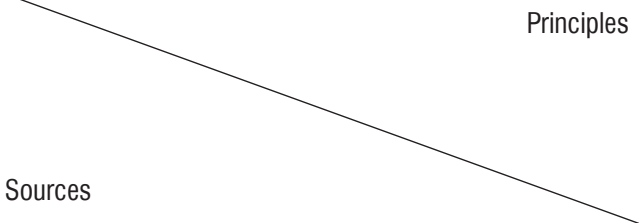 & 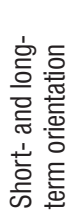 & 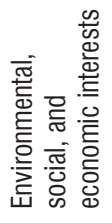 & 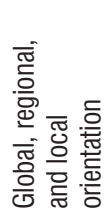 & 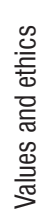 & 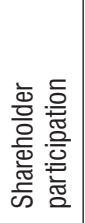 & 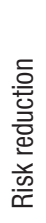 & 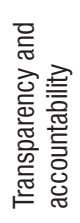 & 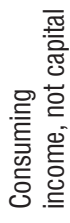 \\
\hline Lambuschangne, Brent (2004), pp. 104-115 & $\mathrm{X}$ & $X$ & $X$ & & $x$ & & $x$ & \\
\hline Gereis, Huemann, Martinuzzi (2009) & $X$ & $X$ & $X$ & $\mathrm{x}$ & $\mathrm{x}$ & $x$ & & \\
\hline Turner (2010), pp. 161-170 & $X$ & $X$ & $\mathrm{X}$ & $x$ & $x$ & $\mathrm{x}$ & & \\
\hline Massikomer et al. (2011) & $X$ & $X$ & $X$ & $x$ & & & & \\
\hline Goedknedt, Silvus (2012) & $X$ & $X$ & $\mathrm{X}$ & $\mathrm{x}$ & $\mathrm{x}$ & $x$ & $\mathrm{x}$ & \\
\hline Silvus, Schipper (2012), pp. 21-44 & $\mathrm{X}$ & $X$ & $\mathrm{X}$ & $x$ & & & $\mathrm{x}$ & \\
\hline Gereis (2013), pp. 129-143 & $\mathrm{X}$ & $X$ & $\mathrm{X}$ & $\mathrm{x}$ & & & & \\
\hline Økland (2015), pp. 103-109 & $\mathrm{X}$ & & $X$ & & & $\mathrm{x}$ & & $x$ \\
\hline Total & 8 & 7 & 8 & 6 & 4 & 4 & 3 & 1 \\
\hline
\end{tabular}

Source: Agarwal, Kalmár (2015), p. 8.

Detailed aspects covered by these five areas which are effects of practical experience and theoretical analyses are presented in Table 3.

Table 3. Detailed aspects of social responsibility in project management

\begin{tabular}{|c|c|c|c|c|}
\hline $\begin{array}{l}\text { Perspectives } \\
\text { Leading lines }\end{array}$ & \multicolumn{4}{|l|}{ Process } \\
\hline Environment & $\begin{array}{l}\text { Transport: } \\
\text { - Local orders } \\
\text { - Digital communication } \\
\text { - Traveling } \\
\text { - Logistics }\end{array}$ & $\begin{array}{l}\text { Energy: } \\
\text { - Energy consumption } \\
\text { - C02 emissions } \\
\text { - Clean energy return } \\
\text { - Renewable energy }\end{array}$ & $\begin{array}{l}\text { Water: } \\
\text { - Water quality } \\
\text { - Water consumption } \\
\text { - Water displacement }\end{array}$ & $\begin{array}{l}\text { Waste: } \\
\text { - Recycling } \\
\text { - Disposal } \\
\text { - Contamination and } \\
\text { pollution } \\
\text { - Waste }\end{array}$ \\
\hline Society & $\begin{array}{l}\text { Labour and decent work: } \\
\text { - Employment and filling } \\
\text { positions } \\
\text { - Employees/employers } \\
\text { relations } \\
\text { - Health and safety in the } \\
\text { project } \\
\text { - Training and education } \\
\text { - Organisational learning } \\
\text { - Diversity and equal } \\
\text { - opportunities } \\
\text { - Developing local skills }\end{array}$ & $\begin{array}{l}\text { Society and customers: } \\
\text { - Community support } \\
\text { - Public policy and } \\
\text { compliance } \\
\text { - Customer health and } \\
\text { safety } \\
\text { - Marking products and } \\
\text { services } \\
\text { - Market } \\
\text { communications and } \\
\text { advertising } \\
\text { - Customer privacy }\end{array}$ & $\begin{array}{l}\text { Human rights: } \\
\text { - Non-discrimination } \\
\text { - Child labour } \\
\text { - Forced or compulsory } \\
\text { labour }\end{array}$ & $\begin{array}{l}\text { Ethical behaviour: } \\
\text { - Investment and } \\
\text { procurement practices } \\
\text { - Bribery and corruption } \\
\text { - Anti-competitive } \\
\text { behaviour }\end{array}$ \\
\hline
\end{tabular}




\begin{tabular}{|c|c|c|c|c|}
\hline $\begin{array}{l}\text { Perspectives } \\
\text { Leading lines }\end{array}$ & \multicolumn{3}{|l|}{ Process } & Product \\
\hline Economy & $\begin{array}{l}\text { Return on Investment (ROI): } \\
\text { - Benefit cost ratio } \\
\text { - Direct financial benefits } \\
\text { - Internal rate of return } \\
\text { - External rate of return } \\
\text { - Net present value }\end{array}$ & $\begin{array}{l}\text { Business agility: } \\
\text { - Flexibility/optionality } \\
\text { in the project } \\
\text { - Increased business } \\
\text { flexibility }\end{array}$ & $\begin{array}{l}\text { Economic stimulation: } \\
\text { - Local economic } \\
\text { impact } \\
\text { - Indirect benefits }\end{array}$ & \\
\hline
\end{tabular}

Source: own elaboration based on The GPM Global P5 Standard for Sustainability in Project Management., Ludzie, Planeta, Dobrobyt, Proces i Produkty, Release 1.5, GPM Global (2017).

\section{Survey on project social responsibility in Poland}

Since project social responsibility (PSR) is a totally new subject in both Poland and globally, the authors decided to make a preliminary stock taking of approaches to project social responsibility adopted in organisations operating in Poland. The study was exploratory by nature and the first of its kind in Poland.

The study is based on an inductive approach, which helped in working out a research procedure presented in Figure 1.

\section{Figure 1. Research procedure adopted for the study}

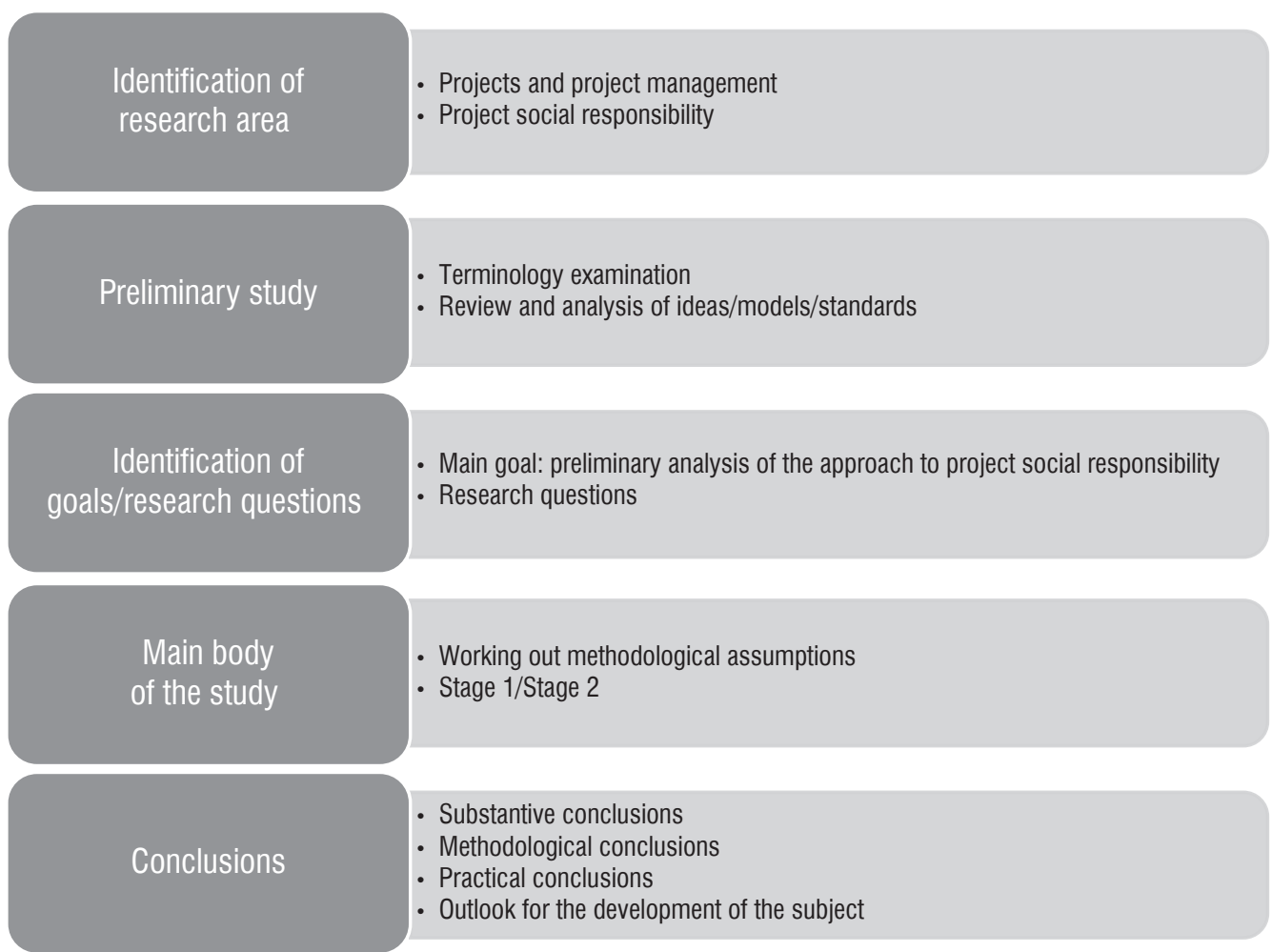

Source: own survey. 
Next, we developed a research model for empirical studies. It is presented in Figure 2.

\section{Figure 2. Research model for empirical studies}

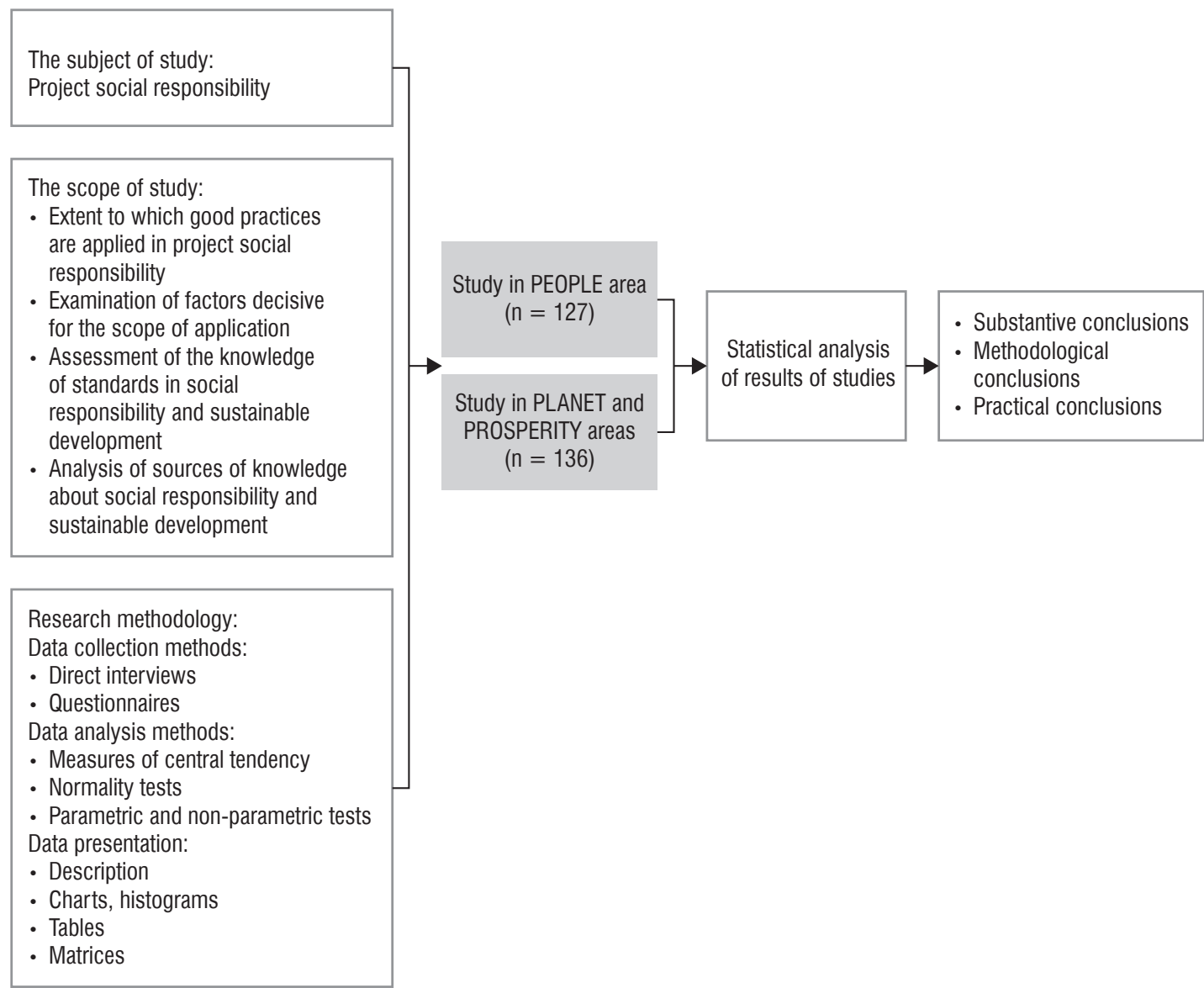

Source: own survey.

Data were collected using computer-assisted telephone interviewing (CATI) on samples consisting of 127 (for PEOPLE) and 136 people (for the areas of PLANET and PROSPERITY) involved in the delivery of projects in their respective companies.

In stage 1 interviews were conducted with 127 respondents, while in stage 2, 136 people were interviewed. The respondents performed diverse functions in their organisations - from managers who supervise projects, through project managers and project team members, down to the staff of units who support projects. They also represented a wide range of industries and economic sectors. Companies covered by the study were strongly differentiated when it comes to their size, intensity of project activities, scope of operations or headquarters location. Nevertheless, we need to stress that despite this differentiation, the sample is not a random one as it is rather a target sample. 
In the study, the respondents were asked to mark the frequency with which specific project social responsibility practices are exercised on the following scale:

$0=\mathrm{I}$ do not know

$1=$ never or in few projects delivered in the organisation

$2=$ usually/in most projects delivered in the organisation

$3=$ always/in each project delivered in the organisation

$9=$ not applicable

The primary conclusion from the survey is that organisations covered by the study have little knowledge and poor awareness of the importance of corporate social responsibility and in particular its links with project management, which is confirmed by only a $3 \%$ share of organisations that declared competences in the field in question.

The synthetic result of the survey (2.18), which informs us that proven good practices were used in most examined cases, was importantly influenced by the fact that the respondents represented an above-average knowledge about corporate social responsibility and project management, as well as good practices in this area. On top of that:

- proven good practices are relatively widely, above average, used with regard to issues formally regulated externally and/or internally, e.g., in the PEOPLE area: customer privacy, health and safety at work for projects, customer health and safety, bribery and corruption practices, public policy/compliance, anti-competitive behaviour, marking of products and services. In the PLANET and PROSPERITY areas such issues have not been identified;

- similarly, widely proven good practices are applied with regard to aspects that are not regulated formally but are viewed as socially relevant, e.g., in the PEOPLE area: labour practices and decent work, equal treatment, diversity and equal opportunities. A vast portion of practices described in the above-mentioned areas are highlighted by, e.g., the European Union, NGOs, etc. Unfortunately, although all aspects within the PLANET area can be seen as socially relevant, the scores in this area were significantly lower than in other areas. Synthetic scores are given in Table 5;

- scores lower than the average were given for the use of proven good practices to intra-project aspects, e.g., in the PEOPLE area: employees/project management relations, market communication and advertising, investment and procurement, training and education or organisational learning. The scores confirm a relatively low project maturity of the examined organisations. In the PLANET area the aspects subject to project management decisions scored clearly lower than in other areas;

Table 5 Average results for individual areas in the study

\begin{tabular}{|l|c|c|}
\hline \multicolumn{1}{|c|}{ Area } & N (number) & M (arithmetic mean) \\
\hline PEOPLE & 127 & 2.50 \\
\hline PLANET & 136 & 1.89 \\
\hline PROSPERITY & 136 & 2.14 \\
\hline
\end{tabular}

Source: own survey. 
- proven good practices with regard to, e.g., child labour and forced or compulsory labour, which in our civilisation are obvious for legal as well as moral reasons, are used to a limited extent;

- proven good practices in the field of collaboration between organisations, project managers and project stakeholders are often underused compared to the needs and capabilities, e.g., with regard to developing local skills and community support. These results are confirmed by studies on stakeholder engagement in projects;

- the highest score was obtained for the issues from the PEOPLE area (mean 2.50), while the issues from the PLANET area scored clearly the lowest (mean 1.89).

The major restriction in the survey is the limited representativeness of the sample. Although we examined more than 250 organisations in total, it allowed us to draw only limited conclusions about the population. The problem stems also indirectly from the fact that it is extremely difficult to identify a population to be researched.

In practical terms, some restrictions result from aspects considered universal in the P5 GPM standard and not necessarily applicable to the reality of organisations operating in Poland.

When it comes to the methodology, we need to say that the interview format could be a limitation to the survey. A telephone conversation lasting 15-20 minutes produces a risk of decreasing reliability of data over time. The respondents were asked to assess practices applied in sensitive areas of operation of companies in which they work. Hence the risk of inflated self-assessment. Nevertheless, the findings suggest that such assessments could emerge only to a limited extent (e.g., low scores in the areas within PLANET, which suggests low awareness and sensitivity of examined organisations to environmental issues in project delivery).

\section{Summary}

Over recent several dozen years, the dissemination of sustainable development agenda has started bearing fruit and has turned into a vast set of concepts, methods, and proven good practices in project management. When analysing the up-till-now effects of promoting the idea of sustainable development and social responsibility in project management, one may see that the subject was approached, above all, as an element of general concepts of corporate social responsibility. However, with the increasing role of effective project delivery at all levels of economic activity, its role as a guarantor of sustainable development of organisations and economies is highlighted. That is the reason why in recent years we have observed gradual introduction of new concepts and special regulations into the economy, including conceptual frameworks, tools and proven good practices of sustainable and socially responsible project management. The subject is still at the initial stage of its development, which is why results of the analysis of practical and theoretical knowledge as well as results of studies highlight the following challenges involved in sustainable and socially responsible project management: 
- the development of the project social responsibility concept in three principal pillars - environmental, social, and economic - with regard to outcomes/deliverables and project processes considering the role/importance of the organisation and its managers;

- making solutions pertaining to the project social responsibility concept part of universal, industry and corporate project management standards and methodologies;

- promoting the idea and tools of project social responsibility among project participants and other project stakeholders;

- creating and implementing mechanisms that motivate practising project social responsibility;

- further development of the conceptual framework and tools, collecting and disseminating good practices in the field of project social responsibility;

- linking the concept of project social responsibility and its solutions with concepts and solutions exercised at higher management levels, in particular with those that belong to corporate social responsibility and corporate governance. Similarly to the project social responsibility idea also these issues closely correlated with the PSR seem to open up new research fields that expand our knowledge about project management.

Studies on project social responsibility conducted by the authors have helped in identifying occurrences that confirm the scale of the above-described challenges facing project management. Remarkably, only 3\% of the examined organisations declared skills and competences in project social responsibility. By investigating into three PSR areas, i.e., issues pertaining to social relations (PEOPLE), benefits and profits (PROSPERITY), and the environment (PLANET) in the group of respondents in Poland, we succeeded in identifying the biggest number of social responsibility related competences in the first area, with the least number of competences in the third area. It may be due to the geopolitical location of Poland, cultural norms and attitudes to work, but it also may be the effect of environmental awareness and ways in which interpersonal relations evolve in this country.

In the absence of similar studies in other parts of the world, we should continue investigating organisations in Poland and carry out comparative studies at the international level. On the one hand, it will increase the size of the sample and, on the other hand, we would be able to observe not just national but also global trends in this field.

From the methodological perspective, in-depth studies that would help in identifying, e.g., key issues involved in the implementation of the project social responsibility idea in companies at the national as well as international levels, would be valuable. It would require conducting direct structured interviews and more target sampling.

Considering the obtained results, studies that would specify success factors in the implementation of project social responsibility principles and possibilities of integrating the PSR with operational systems stemming from the corporate social responsibility strategy would be very valuable. The same can be said about measuring the maturity of companies in project social responsibility.

The authors believe that issues surrounding project social responsibility will move increasingly higher on the organisational management agenda and will become a crucial component 
of sustainable development strategies (at the national and international level). That is why we should expect a growing interest in the subject in the near future and continue studying and monitoring how it evolves.

\section{References}

1. Agarwal, S.R., Kalmár, T. (2015). Sustainability in Project Management: Eight principles in practice. European Umeå School of Business and Economics, p. 8.

2. Birkinshaw, J., Gibson, C. (2004). Building Ambidexterity into an Organization. MIT Sloan Management Review, No. 4.

3. Borys, T., Czaja, S. (2009). Badania nad zrównoważonym rozwojem w polskich ośrodkach naukowych. [In:] D. Kiełczewski (Ed.), Od koncepcji ekorozwoju do ekonomii zrównoważonego rozwoju. Białystok: Wydawnictwo WSB w Białymstoku, pp. 51-58.

4. Bowen, R. (1953), Social Responsibilities of the Businessman. New York: Harper \& Brothers.

5. Brent, A.C. (2005). The Application of Life Cycle Management in Decision-making for Sustainable Development at Government and Corporate Level: The Integration of Project, Asset and Product Life Cycles. Progress in Industrial Ecology - An International Journal, No. 2.

6. Brilman, J. (2002). Nowoczesne koncepcje i metody zarzadzania. Warszawa: PWE, p. 318.

7. Carlowitz von, H.C. (1732/2009). Sylvicultura oeconomica, oder haußwirthliche Nachricht und Naturmäßige Anweisung zur wilden Baum-Zucht (1713), reprint of the $2^{\text {nd }}$ edition from 1732. Remagen-Oberwinter: Verlag Kessel.

8. Eid, M. (2009). Sustainable Development \& Project Management. Cologne: Lambert Academic Publishing, p. 288.

9. Elkington, J. (2004). Enter the Triple Bottom Line. Retrieved from: http://www.johnelkington. com/archive/TBL-elkington-chapter.pdf (accessed: 17.9.2019).

10. Gereis, R, Huemann, M., Martinuzzi, R-A. (2009). Relating Sustainable Development and Project Management. IRNOP IX, Berlin, p. 1. Retrieved from: http://www.pmi.org/learning/ relating-sustainable-development-project-management6497 (accessed: 17.9.2019).

11. Gereis, R. (2013). Re-Thinking Project Initiation and Project Management by Considering Principles of Sustainable Development. [In:] A.J.G. Silvius, J. Tharp J. (Eds.), Sustainability Integration for Effective Project Management. Hershey: IGI Global, pp. 129-143

12. Goedknegt, D., Silvius, A.J.G. (2012). The Implementation of Sustainability Principles in Project Management. 26 ${ }^{\text {th }}$ IPMA World Congress, Crete.

13. Jakubczyk, K., Kitowski, P. (2015). Społecznie odpowiedzialny projekt - opracowanie definicji na podstawie przeglądu literatury z zakresu społecznej odpowiedzialności i zarządzania projektami. e-mentor, No. 12. Retrieved from: http://www.e-mentor.edu.pl/artykul/index/ numer/62/id/1210 (accessed: 11.9.2019).

14. Klimczuk-Kochańska, M. (2016). Wkład Petera F. Druckera w rozwój teorii zarządzania. [In:] K. Klincewicz (Ed.), Zarządzanie, organizacje i organizowanie - przegląd perspektyw teoretycznych. Warszawa: Wydawnictwo Naukowe Wydziału Zarządzania Uniwersytetu Warszawskiego, pp. 70-71. 
15. Labuschagne, C., Brent, A.C. (2004). Sustainable Project Life Cycle Management: Aligning Project Management Methodologies with the Principles of Sustainable Development. PMSA International Conference.

16. Labuschagne, C, Brent, A.C. (2005). Sustainable Project Life Cycle Management: The Need to Integrate Life Cycles in the Manufacturing Sector. International Journal of Project Management, No. 2.

17. Malthus, Th. (1798). An Essay on the Principle of Population. London: J. Johnson.

18. McKinlay, M. (2008). Where Is Project Management Running to...? keynote address delivered at the $22^{\text {nd }}$ World Congress of the International Project Management Association, Rome.

19. Meadows, D.H., Meadows, D.I., Randers, J., Behrens, III W.W. (1972). The Limits to Growth. New York: Universe Books. Polish edition: Meadows, D.H., Meadows, D.I., Randers, J., Behrens, III W.W. (1973). Granice wzrostu. Warszawa: PWE, p. 32.

20. Mesarović, M.D., Pestel, E. (1975). Mankind at the Turning Point: The Second Report to the Club of Rome. Hutchinson.

21. Mesarović, M.D., Pestel, E., Rączkowska, W., Rączkowski, St. (1977). Drugi Raport dla Klubu Rzymskiego. Warszawa: PWE.

22. Messikomer, C., Huemann, M., Dominguez, O., Gareis, R., Navarro-Flores, O., Morgese, P. (2011), Sustainability and Project Management: The Future is Now, PMI (2011), Retrieved from: http://www.pmi.org/learning/academic-research/ /media/PDF/Research/ROWS\%20 -92\%20NA\%202011\%20Sustainability\%20-\%20Slides.ashx (accessed: 25.9.2019).

23. Nieto-Rodriguez, A. (2012). The Focused Organizations. London: Gower, p. 38.

24. Økland, A. (2015). Gap Analysis for Incorporating Sustainability in Project Management. Procedia Computer Science, No 64, pp. 103-109.

25. O’Reilly, Ch., Tushman M.L. (2013). Organizational Ambidexterity: Past, Present and Future. Academy of Management Perspectives, Vol. 27, No. 4, pp 324-338.

26. Our Common Future. Report of the World Commission on Environment and Development (1987). Retrieved from: http://www.un-documents.net/our-common-future.pdf; http://www. un.org/documents/ga/res/42/ares42-187.htm (accessed: 15.8.2019).

27. Pigou, A.C. (1920). The Economics of Welfare. London: Macmillan and Company.

28. PMI Annual Report (2013). Newtown Square: Project Management Institute, p. 1.

29. PMI's Industry Growth Forecast, Project Management between 2010 and 2020(2010). Newtown Square: Project Management Institute, p. 2.

30. Problems of the human environment; report of the Secretary-General (1969). New York: United Nations, Economic and Social Council, E/4667.

31. Project Management Job Growth and Talent Gap Report 2017-2027(2017). Newtown Square: Project Management Institute.

32. Roland, R., Tirole, J. (2009). Individual and Corporate Social Responsibility. IZA Discussion Papers, No. 4570, Bonn: Institute for the Study of Labor.

33. Schoper, Y-G., Waldt, A., Ingason, H.T., Friedgeirson, T.V. (2017). Projectification in Western Economies: A comparative Study of Germany, Norway, and Iceland. International Journal of Project Management, No. 8. 
34. Silvius, G, Schipper, R. (2010). A Maturity Model for Integrating Sustainability in Projects and Project Management. 24 ${ }^{\text {th }}$ World Congress of the International Project Management Association, Istanbul, p. 6.

35. Silvius, A.J.G., Schipper, R. (2012). Sustainability and Projects. [In:] A.J.G. Silvius, R. Schipper, J. Planko, J. van den Brink, A. Köhler (Eds.), Sustainability in Project Management. Farnham: Gower Publishing, pp. 21-44.

36. Silvius, A.J.G., Schipper, R. (2014a). Sustainability in Project Management: A Literature Review and Impact Analysis. Social Business, No. 1, pp. 63-96.

37. Silvus, A.J.G., Schipper, R. (2014b). Sustainability in Project Management Competencies: Analyzing the Competence Gap of Project Manages, Journal of Human Resources and Sustainability, No. 2, pp. 40-58.

38. Społeczna odpowiedzialność działalności projektowej (2019). M. Trocki (Ed.), Warszawa: Oficyna Wydawnicza SGH.

39. The GPM Global P5 Standard for Sustainability in Project Management., People, Planet, ProsperityDobrobyt, Process, and Products, Release 1.5. GPM Global (2017). Retrieved from: https:// greenprojectmanagement.org/the-p5-standard (accessed: 27.10.2019).

40. Top 100 Global Infrastructure Projects (2010). CG/LA Infrastructure.

41. Trocki, M., Juchniewicz, M. (2017). Social responsibility of projects - the essence and results of survey, in: Management in the time of networks, cross-cultural activities and flexible organisations. J. Teczke, P. Buła (scientific editors), International Management Foundation, Cracow: Cracow University of Economics, pp. 353-366.

42. Trocki, M. (2019). Podejścia badawcze do zarządzania projektami - geneza i ewolucja. Przegląd Organizacji, No. 1, pp. 3-9.

43. Turner, J.R. (2010). Responsibilities for Sustainable Development in Project and Program Management. [In:] H. Knoepfel (Ed.), Survival and Sustainability as Challenges for Projects. Zurich: International Project Management Association, pp. 161-170.

44. Wołczek, P. (2014). Ewolucja podejścia do koncepcji zrównoważonego rozwoju na arenie międzynarodowej. Prace Naukowe Uniwersytetu Ekonomicznego we Wrocławiu, No. 1, pp. 207-208. 